\title{
Synthesis and characterization of ferrocene-based thiosemicarbazones along with their computational studies for potential as inhibitors for SARS-CoV-2
}

\author{
Rifat Jawaria ${ }^{1}$ Muhammad Usman Khan ${ }^{2,3} \cdot$ Mazhar Hussain $^{4} \cdot$ Shabbir Muhammad $^{5} \circledast$ Muhammad Sagir $^{6}$. \\ Amjad Hussain $^{2} \cdot$ Abdullah G. Al-Sehemi $^{7}$
}

Received: 22 May 2021 / Accepted: 16 July 2021 / Published online: 26 July 2021

(c) Iranian Chemical Society 2021

\begin{abstract}
Ferrocene and its derivatives are vital class of organometallic compounds having extensive biological activities. Six novel ferrocene-based thiosemicarbazones have been synthesized through the condensation reaction of acetyl ferrocene with differently substituted thiosemicarbazide. Furthermore, we used state-of-the-art computational docking approach to explore the theoretical aspects for possible antiviral potential of our synthesized compounds. All the six compounds were docked with $\mathrm{M}^{\text {pro }}$ protein of SARS-CoV-2, which is very crucial protein for viral replication. Among the six derivatives, compounds 2 and 4 showed higher binding affinities with binding energy of -6.7 and $-6.9 \mathrm{kcal} / \mathrm{mol}$, respectively. The visualization of intermolecular interactions between synthesized derivatives and $\mathrm{M}^{\text {pro }}$ protein illustrated that each of compounds $\mathbf{2}$ and $\mathbf{4}$ forms two hydrogen bonds accompanied by important hydrophobic interactions. The comparison of binding affinities with some recently approved drugs like remdesivir, chloroquine and hydroxychloroquine molecules are also made. The calculated binding energies of remdesivir, chloroquine and hydroxychloroquine molecules with $\mathrm{M}^{\text {pro }}$ of COVID-19 was found to be $-7.00,-5.20$ and $-5.60 \mathrm{kcal} / \mathrm{mol}$, respectively. The binding energy of compound $4(-6.9 \mathrm{kcal} / \mathrm{mol})$ was almost equal to the remdesivir and greater than the binding energies of chloroquine and hydroxychloroquine. It is expected from the current investigation that our synthesized ferrocene-based thiosemicarbazones might have potential for drug against SARS-CoV-2.
\end{abstract}

Muhammad Usman Khan

usmankhan@uo.edu.pk

Shabbir Muhammad

mshabbir@kku.edu.sa

1 Department of Chemistry, Khwaja Fareed University of Engineering \& Information Technology,

Rahim Yar Khan 64200, Pakistan

2 Department of Chemistry, University of Okara, Okara 56300, Pakistan

3 Department of Applied Chemistry, Government College University, Faisalabad 38000, Pakistan

4 Institute of Chemical Sciences, Bahauddin Zakariya University, Multan 60800, Pakistan

5 Department of Physics, College of Science, King Khalid University, P.O. Box 9004, Abha 61413, Saudi Arabia

6 Department of Chemical Engineering, Khwaja Fareed University of Engineering \& Information Technology, Rahim Yar Khan 64200, Pakistan

7 Department of Chemistry, College of Science, King Khalid University, P.O. Box 9004, Abha 61413, Saudi Arabia 


\section{Graphical abstract}

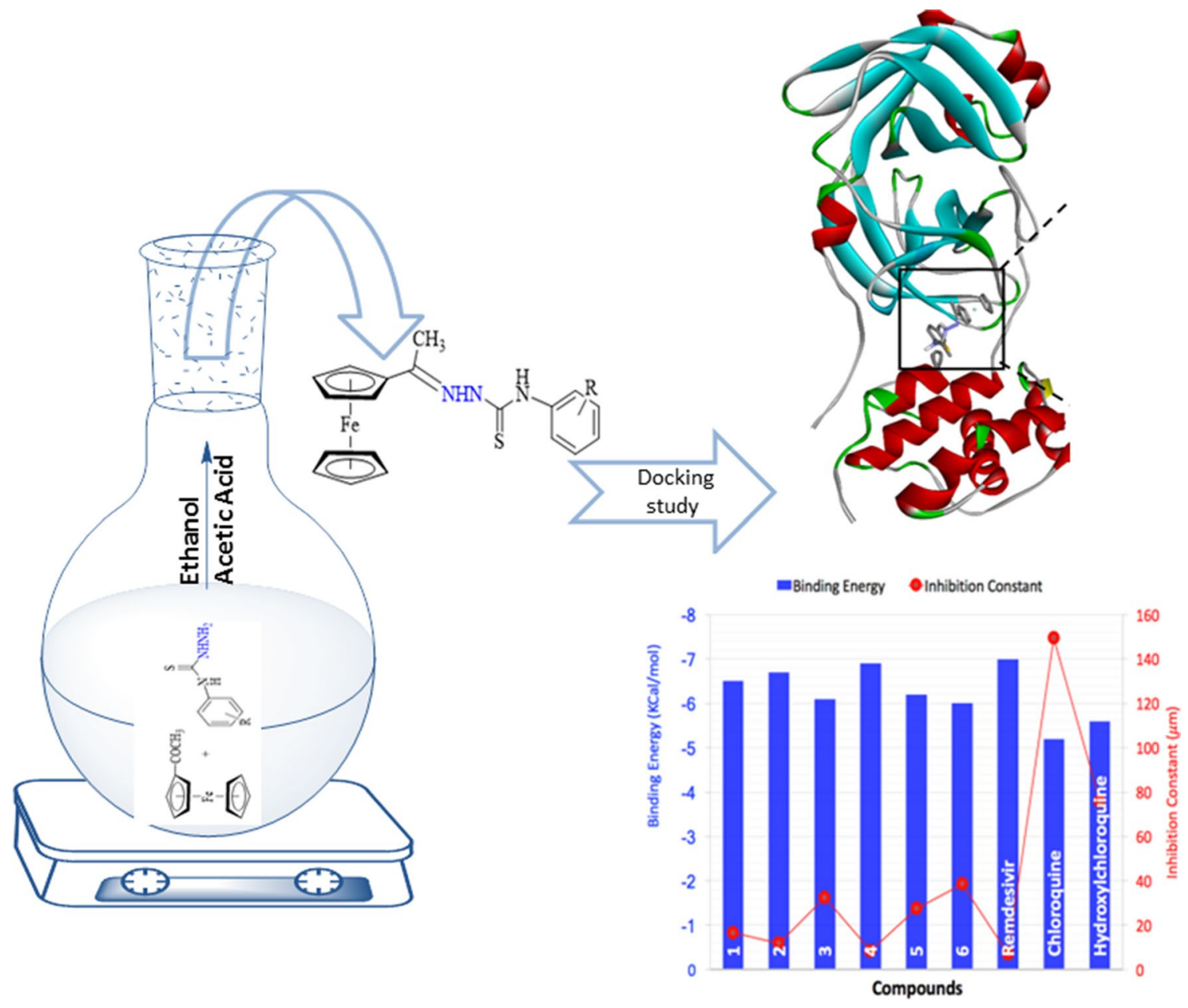

Keywords Ferrocene $\cdot$ Thiosemicarbazones $\cdot$ Main protease $\cdot$ SARS-CoV-2 $\cdot$ COVID-19

\section{Introduction}

Ferrocene, an 18-electron organometallic sandwich complex comprised of an iron(II) ion located between two cyclopentadiene $(\mathrm{Cp})$ ligands $[1,2]$. Due to the rich chemistry of the iron(II) center, the stability in aerobic and aqueous media coupled with aromaticity, captivating structure, properties, and reactivity, ferrocene has become a molecule of considerable interest [3]. The lipophilic sandwich-like molecule and its derivatives are water, air and thermally stable [4]. The iron(II) ion of ferrocene which is sandwiched between two Cp ligands, acts as an "atomic ball-bearing" that enable the $\mathrm{Cp}$ rings to rotate freely (the barrier to rotation is 0.9 (3) $\mathrm{kcal} \mathrm{mol}{ }^{-1}$, having preferred eclipsed conformation) [5]. Ferrocene can also undergo reversible oxidation to form ferrocenium $\left(\mathrm{Fc}^{+}\right)$. Ferrocene is widely applicable scaffold in material sciences, catalysis, diagnostic applications and medicinal as well as synthetic fields [6-10]. Potent antimalarial have been formed by the combination of known antimalarial drugs with organometallic compounds. Therapeutic activity has been enhanced by incorporating ferrocene into a bioactive drug molecule [11]. Ferrocene is an excellent pharmacophore which exhibits physicochemical properties having good effects on the living matter [12, 13]. In non-aqueous solutions, ferrocene show extremely high electrochemical reaction rates, which permit them to serve as quasi-reference substances in electrochemical measurements [14]. They also show excellent solubility in various organic solvents [15]. To inhibit the growth of cancer, the free radical scavenging and the superoxide reaction of ferrocene are useful. Ferrocene derivatives have been applicable in biological activities, such as antioxidant, anti-HIV, antineoplastic, DNA-cleaving activities, antitumor, antimalarial, anticonvulsant, antimicrobial, and analgesic among 
which antimalarial and antitumor activities of ferrocene derivatives have attracted remarkable interest. Due to the favorable combination of physical and chemical properties, ferrocene-derived compounds are employed as hematopoietic substances, electronic materials, high-octane additives to motor fuel and metallic coatings [16]. Polymers based on ferrocene have been paying attention due to numerous applications such as biophysics, biosensing [17, 18], surface science and biomedical engineering [19]. Ferrocene derivatives play important role in non-interlocked synthetic molecular machines [20, 21]. Ferrocene-containing compounds have also been applicable in other areas that include electroactive materials [6, 22-26], drug design mediators of protein redox reactions [27], organic synthesis [28], molecular sensing and biochemistry [29-34]. Ferrocene derivatives also play a vital role as catalysts because they are susceptible to the influence of electronic environment, while on the other hand, recent destructive attack of COVID-19 (by SARS-CoV-2 virus) on the world community have forced the scientific societies to left no stone unturned for finding a possible therapeutic drug for it. It is immense important to search every possible new drug candidate for potential use against SARS-CoV-2. It is also imperative to mention that aminoquinoline-ferrocenyl derivatives were already investigated experimentally against different strains of virus where these derivatives have shown antiviral activities against feline and human (SARS) coronavirus and malaria [35]. In the backdoor of above situation, herein, our aim is twofold to synthesize new biologically important derivatives and also to study the potential of our indigenously designed compounds for potential therapeutic candidates against SARS-CoV-2 by molecular docking studies.

\section{Experimental and computational procedures}

\section{Manufacture and models}

The solvents and chemicals were obtained in pure form from Merck and were not purified further. Fisher-Johns melting point apparatus was used to record melting points. FT-IR
(450-4000 $\mathrm{cm}^{-1}$ ) spectrum was taken with Shimadzu Prestige-21 FT-IR spectrophotometer. The UV-Visible spectrophotometer (UV-1700 Pharmaspec) was used to record electronic spectra. To record ${ }^{13} \mathrm{C}$ or ${ }^{1} \mathrm{H}-\mathrm{NMR}$ spectra, a Bruker AM 300 spectrometer (Rheinstetten-Forchheim, Germany) uses DMSO as solvent and TMS as internal standard. The proton nuclear magnetic resonance spectroscopy was recorded at $300 \mathrm{MHz}$, while ${ }^{13} \mathrm{C}-\mathrm{NMR}$ at $75 \mathrm{MHz}$ or 62.9 MHz. Thin-layer chromatography was performed using aluminum sheets coated with silica.

\section{General method for the synthesis of thiosemicarbazones derivative of Ferrocene}

The solutions of acetylferrocene $(3.30 \mathrm{mmol})$ and substituted thiosemicarbazide (3.3. mmol) were prepared in ethanol $(20 \mathrm{ml})$. Both solutions were mixed, and acetic acid was added in catalyst amount. The above mixture was refluxed for $5 \mathrm{~h}$ and yielded radish orange crystal on cooling to room temperature. The products were filtered, washed several times with cold ethanol and dried subsequently. Orange color crystals were obtained through recrystallization from ethanol using the slow evaporation method (Scheme 1).

\section{4-(2,3-dimethylphenyl)-1-(1-ferrocenylethyl) thiosemicarbazone (1)}

Yield, 78\%; Orange crystalline: $\mathrm{mp}, 162{ }^{\circ} \mathrm{C}$; “IR (KBr), V $\left(\mathrm{cm}^{-1}\right):$ 3085, $3309(\mathrm{NH}), 1541(\mathrm{C}=\mathrm{N}), 1150(\mathrm{C}=\mathrm{S}) .{ }^{1} \mathrm{H}-$ NMR (DMSO), ${ }^{\delta}$ (ppm): 4.189-4.885 (m, Cp-ring), 2.096 $\left(3 \mathrm{H}, \mathrm{s}, \mathrm{CH}_{3}-\mathrm{C}=\mathrm{N}\right), 2.269\left(6 \mathrm{H}, \mathrm{d},\left(\mathrm{Ph}-2,3 \mathrm{CH}_{3}\right), 9.648\right.$ (1H, s, CS-NH), $10.272(1 \mathrm{H}, \mathrm{s}, \mathrm{N}-\mathrm{NH}), 7.08-7.222(\mathrm{~m}$, Ph-ring). ${ }^{13} \mathrm{C}-\mathrm{NMR}$ (DMSO), ${ }^{\delta}$ (ppm): $176.91(\mathrm{C}=\mathrm{S}), 151.10$ $(\mathrm{C}=\mathrm{N}), 15.29\left(\mathrm{CH}_{3}-\mathrm{C}=\mathrm{N}\right), 14.07\left(\mathrm{CH}_{3}-\right.$ Phenyl $), 20.12$ $\left(\mathrm{CH}_{3}\right.$ - Phenyl), 67.50, 69.11, 69.86, 82.99, 124.95, 126.13, 127.72, 133.36, 136.64, 138.06 (Aromatic \& $\mathrm{Cp}$ ring $\mathrm{C}$ and CH). "EIMS, m/z (rel. int.):"405(M+1 $\left.\mathrm{M}^{+}, 15\right), 284(59), 227(83)$, 211(23), 185(100), 162(20), 146(28), 121(40), 106(35), 56(14).
Scheme 1 Synthetic pathway of entitled compounds

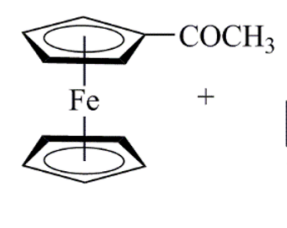<smiles>NNC(=S)Nc1ccccc1</smiles><smiles>CCCCC(C)=O</smiles><smiles>CC(=NNC(=S)Nc1ccccc1)c1ccccc1F</smiles>

$\begin{array}{ll}\text { (1) } & R=2, \text { 3-dimethyl } \\ \text { (2) } & R=2,5 \text {-dimethyl } \\ \text { (3) } & R=3,4 \text {-dimethyl }\end{array}$
$R=2$, 4-dimethyl
$R=2,6$-dimethyl
$R=3,5$-dimethyl 


\section{4-(2,5-dimethylphenyl)-1-(1-ferrocenylethyl)} thiosemicarbazone (2)

Yield, 75\%; Orange crystalline: $\mathrm{mp}, 142{ }^{\circ} \mathrm{C}$; "IR (KBr), $\mathrm{V}$ $\left(\mathrm{cm}^{-1}\right):$ 3045, $3311(\mathrm{NH}), 1541(\mathrm{C}=\mathrm{N}), 1197(\mathrm{C}=\mathrm{S}) .{ }^{1} \mathrm{H}-$ NMR (DMSO), ${ }^{\delta}$ (ppm): 4.189-4.885 (m, Cp-ring), 2.096 $\left(3 \mathrm{H}, \mathrm{s}, \mathrm{CH}_{3}-\mathrm{C}=\mathrm{N}\right), 2.269\left(6 \mathrm{H}, \mathrm{d},\left(\mathrm{Ph}-2,3 \mathrm{CH}_{3}\right), 9.648\right.$ $(1 \mathrm{H}, \mathrm{s}, \mathrm{CS}-\mathrm{NH}), 10.272(1 \mathrm{H}, \mathrm{s}, \mathrm{N}-\mathrm{NH}), 7.08-7.222$ (m, Ph-ring) ${ }^{13} \mathrm{C}-\mathrm{NMR}$ (DMSO), ${ }^{8}(\mathrm{ppm}): 176.91(\mathrm{C}=\mathrm{S}), 151.10$ $(\mathrm{C}=\mathrm{N}), 15.29\left(\mathrm{CH}_{3}-\mathrm{C}=\mathrm{N}\right), 14.07\left(\mathrm{CH}_{3}-\right.$ Phenyl), 20.12 $\left(\mathrm{CH}_{3}-\right.$ Phenyl), 67.50, 69.11, 69.86, 82.99, 124.95, 126.13, 127.72, 133.36, 136.64, 138.06 (Aromatic \& Cp ring C and $\mathrm{CH})$. EIMS, $\mathrm{m} / \mathrm{z}$ (rel. int.): 405( $\left.\mathrm{M}^{+}, 40\right), 284(100)$, 227(100), 211(47), 185(71), 162(23), 146(33), 121(70), 106(38), 56(19).

\section{4-(3,4-dimethylphenyl)-1-(1-ferrocenylethyl) thiosemicarbazone (3) [36]}

Yield, 81\%; Orange crystalline: $\mathrm{mp}, 154{ }^{\circ} \mathrm{C}$; "IR ( $\left.\mathrm{KBr}\right)$, V $\left(\mathrm{cm}^{-1}\right): 3319,3076(\mathrm{NH}), 1533(\mathrm{C}=\mathrm{N}), 1203(\mathrm{C}=\mathrm{S})$. ${ }^{1} \mathrm{H}-\mathrm{NMR}(\mathrm{CDCl} 3),{ }^{\delta}(\mathrm{ppm}) ; 4.06-4.48$ (m, Cp-ring), 2.11 ( $\left.3 \mathrm{H}, \mathrm{s}, \mathrm{CH}_{3}-\mathrm{C}=\mathrm{N}\right), 2.30\left(6 \mathrm{H}, \mathrm{s}, \mathrm{Ph}-2,5 \mathrm{CH}_{3}\right), 7.75(1 \mathrm{H}$, s, CS-NH), 8.29 (1H, s, N-NH), 7.029-7.65 (m, Phenylring). ${ }^{13} \mathrm{C}-\mathrm{NMR}$ (DMSO), ${ }^{8}(\mathrm{ppm}): 175.83(\mathrm{C}=\mathrm{S}), 151.79$ $(\mathrm{C}=\mathrm{N}), 18.92\left(\mathrm{CH}_{3}-\mathrm{C}=\mathrm{N}\right), 15.50\left(\mathrm{CH}_{3}-\right.$ Phenyl $), 19.45$ $\left(\mathrm{CH}_{3}\right.$ - Phenyl), 67.53, 69.13, 69.94, 82.85, 122.69, 126.28, 128.97, 132.98, 135.78, 136.74 (Aromatic \& Cp ring C and $\mathrm{CH})$. EIMS, $\mathrm{m} / \mathrm{z}$ (rel. int.):"405( $\left.\mathrm{M}^{+}, 7.8\right), 284(32)$, 227(100), 211(26), 185(71), 162(30), 146(40), 121(51), 106(34), 56(20).

\section{4-(2,4-dimethylphenyl)-1-(1-ferrocenylethyl) thiosemicarbazone (4)}

Yield, 76\%; Orange crystalline: $\mathrm{mp}, 138{ }^{\circ} \mathrm{C}$; "IR (KBr), V $\left(\mathrm{cm}^{-1}\right):$ 3093, $3309(\mathrm{NH}), 1558(\mathrm{C}=\mathrm{N}), 1198(\mathrm{C}=\mathrm{S}) .{ }^{1} \mathrm{H}-$ NMR $\left(\mathrm{CDCl}_{3}\right),{ }^{\delta}(\mathrm{ppm}): 4.194-4.8179$ (m, Cp ring), 2.263 $\left(3 \mathrm{H}, \mathrm{s}, \mathrm{CH}_{3}-\mathrm{C}=\mathrm{N}\right), 2.4339\left(6 \mathrm{H}, \mathrm{d}, \mathrm{Ph}-2,6 \mathrm{CH}_{3}\right), 8.7472$ $(1 \mathrm{H}, \mathrm{s}, \mathrm{CS}-\mathrm{NH}), 9.4826(1 \mathrm{H}, \mathrm{s}, \mathrm{N}-\mathrm{NH}), 7.2806-7.992$ (m, Ph-ring). ${ }^{13} \mathrm{C}-\mathrm{NMR}$ (DMSO), ${ }^{8}(\mathrm{ppm}): 176.70(\mathrm{C}=\mathrm{S})$, $151.13(\mathrm{C}=\mathrm{N}), 17.74\left(\mathrm{CH}_{3}-\mathrm{C}=\mathrm{N}\right), 15.32\left(\mathrm{CH}_{3}-\right.$ Phenyl), $20.63\left(\mathrm{CH}_{3}-\right.$ Phenyl), 67.48, 69.11, 69.66, 82.97, 126.28, 127.72, 130.56, 134.06, 135.25, 135.25 (Aromatic \& Cp ring $\mathrm{C}$ and $\mathrm{CH}$ ). "EIMS, $\mathrm{m} / \mathrm{z}$ (rel. int.):" $405\left(\mathrm{M}^{+}, 11\right), 284(43)$, 227(100), 211(30), 185(86), 162(28), 146(45), 121(41), 106(29), 56(15)0.666.

\section{4-(2,6-dimethylphenyl)-1-(1-ferrocenylethyl) thiosemicarbazone (5)}

Yield, 73\%; Orange crystalline: $\mathrm{mp}, 195^{\circ} \mathrm{C}$; "IR (KBr), V $\left(\mathrm{cm}^{-1}\right): 3075,3290(\mathrm{NH}), 1541(\mathrm{C}=\mathrm{N}), 1175(\mathrm{C}=\mathrm{S})$. $\left.{ }^{1} \mathrm{H}-\mathrm{NMR} "\left(\mathrm{CDCl}_{3}\right),\right),{ }^{1} \mathrm{H}-\mathrm{NMR}$ (DMSO), ${ }^{\delta}(\mathrm{ppm}): 4.179-4.866$ (m, Cp-ring), 2.490 (3H, s, $\left.\mathrm{CH}_{3}-\mathrm{C}=\mathrm{N}\right), 2.210(6 \mathrm{H}, \mathrm{d}, \mathrm{Ph}-3,4$ $\left.\mathrm{CH}_{3}\right), 9.570(1 \mathrm{H}, \mathrm{s}, 58 \mathrm{CS}-\mathrm{NH}), 10.265(1 \mathrm{H}, \mathrm{s}, \mathrm{N}-\mathrm{NH})$ 6.991-7.322 (m, Ph-ring). ${ }^{13} \mathrm{C}-\mathrm{NMR}\left(\mathrm{CDCl}_{3}\right),{ }^{8}(\mathrm{ppm})$ : 149.37(C=S), $148.04(\mathrm{C}=\mathrm{N}), 19.28\left(\mathrm{CH}_{3}-\mathrm{C}=\mathrm{N}\right), 14.64$ ( $\mathrm{CH}_{3}$ - Phenyl), 24.25 ( $\mathrm{CH}_{3}$ - Phenyl), 67.04, 68.15, 68.56, 69.35, 69.86, 70.36, 70.74, 74.75, 82.23, 126.21, 126.25, 127.85, 128.36, 128.77, 130.57, 135.45, 136.43 (Aromatic \& $\mathrm{Cp}$ ring $\mathrm{C}$ and $\mathrm{CH})$. "EIMS, $\mathrm{m} / \mathrm{z}$ (rel. int.):" $405\left(\mathrm{M}^{+}, 81\right)$, 284(41), 227(100), 211(27), 185(92), 162(26), 146(39), 121(40), 106(18), 56(13).

\section{4-(3,5-dimethylphenyl)-1-(1-ferrocenylethyl) thiosemicarbazone (6)}

Yield, 75\%; Orange crystalline: $\mathrm{mp}, 154{ }^{\circ} \mathrm{C}$; IR (KBr), V $\left(\mathrm{cm}^{-1}\right):$ 3105, $3335(\mathrm{NH}), 1544(\mathrm{C}=\mathrm{N}), 1209(\mathrm{C}=\mathrm{S}),{ }^{1} \mathrm{H}-$ NMR (DMSO), ${ }^{8}$ (ppm): 4.199-4.872 (m, Cp-ring), 2.211 (6H, d, Ph-3,5 $\mathrm{CH}_{3}$ ), 2.490 (3H, s, $\left.\mathrm{CH}_{3} \mathrm{C}=\mathrm{N}\right), 9.656$ ( $1 \mathrm{H}, \mathrm{s}$, CS-NH), 10.244 (1H, s, N-NH), 7.084-7.333 (m, Ph-ring). ${ }^{13} \mathrm{C}-\mathrm{NMR}\left(\mathrm{CDCl}_{3}\right),{ }^{\delta}(\mathrm{ppm}): 143.57(\mathrm{C}=\mathrm{S}), 135.25(\mathrm{C}=\mathrm{N})$, $23.23\left(\mathrm{CH}_{3}-\mathrm{C}=\mathrm{N}\right), 14.71\left(\mathrm{CH}_{3}-\right.$ Phenyl $), 24.52\left(\mathrm{CH}_{3}-\right.$ Phenyl), 67.06, 68.33, 68.64, 69.47, 69.93, 70.56, 70.84, 82.05, 125.88, 126.09, 127.43, 127.88 (Aromatic \& $\mathrm{Cp}$ ring $\mathrm{C}$ and CH). “EIMS, m/z (rel. int.):"405(M $\left.\mathrm{M}^{+}, 9\right), 284(73), 227(64)$, 211(36), 185(100), 162(14), 146(29), 121(51), 106(26), $56(15)$.

\section{Computational docking protocols}

All the protein docking calculations were performed using AutoDock Tools [37] and AutoDockVina (ADV) [38] programs, while docking results were visualized by Discovery Studio visualizer [39]. The three-dimensional structures of ligands were prepared through Gauss View [40] and converted to their respective PDBQT formats using MGL tools. The crucial protein of main protease $\left(\mathrm{M}^{\mathrm{pro}}\right)$ of SARS-CoV 2 (PDB ID: 6LU7) [41] was used as the rigid receptor because $\mathrm{M}^{\text {pro }}$ plays a very crucial role in virus replication process. AutoDock MGL Tools 1.5.6 were used to prepare the receptor protein. Preparation of receptor involved removal of previously attached ligand with 6LU7, removal of all water molecules, addition of polar hydrogen atoms, addition of Kollman charges and finally to save it in PDBQT format. The docking was performed using ADV with exhaustiveness value of 8 , remaining parameters of the software were sustained as a default, and all bonds of the ligand were allowed to move freely, taking receptor as a rigid. 


\section{Result and discussion}

In the IR spectra, of compounds 1-6 bands, which assigned to $v(\mathrm{NH})$, and $v(\mathrm{C}=\mathrm{S})$ were appeared at $3319-3085 \mathrm{~cm}^{-1}$ and $1209-1150 \mathrm{~cm}^{-1}$, respectively. The band for $v(-\mathrm{C}=\mathrm{N}-)$ was showed at $1558-1533 \mathrm{~cm}^{-1}$, and disappearance of carbonyl $(\mathrm{C}=\mathrm{O})$ stretch at $1688 \mathrm{~cm}^{-1}$ in the IR spectrum signified the formation of novel compounds. In the ${ }^{1} \mathrm{H}$ NMR spectra, the signal assigned to (NH-N) proton, present in 1-6 compounds, appeared at $9.4826-10.272 \mathrm{ppm}$ as a singlet, owing to the existence of two electronegative atoms connected to proton which sequentially increase the deshielding effect of proton. The singlet peak for one proton of CS-NH was observed at the region of 8.7472-9.656 ppm. This signal was shifted to downfield region due to the deshielding effect of electronegative sulfur $(\mathrm{C}=\mathrm{S})$ and the neighboring amine nitrogen. The signal for three protons of $\mathrm{CH}_{3}-\mathrm{C}=\mathrm{N}$ is showed as singlet in the region of 2.096-2.490 ppm. The signal for di-substituted methyl protons present in 1-6 compounds appeared as singlet signal in the range of 2.210-2.269 ppm. All the signals of aromatic protons and $\mathrm{Cp}$-ring were appeared in the predicted regions. In ${ }^{13} \mathrm{C}$ NMR, the signal of $\mathrm{C}=\mathrm{N}$ was appeared in the region of 135.25-151.79 ppm, and the signal assigned to thioamide $(\mathrm{C}=\mathrm{S})$ moiety was noticed at $143.57-176.91 \mathrm{ppm}$. All the methyl carbons were appeared at $14.07-24.52 \mathrm{ppm}$, while the peaks appeared at $67.04-138.06 \mathrm{ppm}$ correspond to the aromatic carbons.

The mass spectra of the compounds 1-6 exhibited molecular ion peaks at $\mathrm{m} / \mathrm{z} 405\left(\mathrm{M}^{++}, 40\right)$, in agreement with their molecular formula.

\section{Molecular docking and antiviral activity}

The molecular docking calculations for the ferrocenylethyl-thiosemicarbazone derivatives were performed to estimate their binding affinities against the main protease $\left(\mathrm{M}^{\mathrm{pro}}\right)$ enzyme of SARS-CoV-2, which is very important for SARS$\mathrm{CoV}-2$ replication process. The $\mathrm{M}^{\text {pro }}$ is a key enzyme of SARS CoV-2 and plays a key role in the proteolytic maturation and life cycle of SARS CoV-2 [42, 43]. Thus, inhibition of $\mathrm{M}^{\text {pro }}$ can be a potential target for the inhibition of SARS$\mathrm{CoV}-2$ life cycle at transcription or translation phase. The 3D structure of main protease (PDB ID:6LU7) was obtained from RSCB PDB database (https://www.rcsb.org/). The SDF files of selected ligands were generated indigenously.

\section{Binding affinities of ligand and protein complexes}

The binding affinities of ferrocenylethyl-thiosemicarbazone derivatives against $\mathrm{M}^{\text {pro }}$ were determined in terms of their
Table 1 Binding energies $(\mathrm{kcal} / \mathrm{mol})$ and inhibition constants $\mathrm{Ki}$ of ferrocenylethyl-thiosemicarbazone derivatives as docked to the SARS-CoV-2 main protease ( $\left.\mathrm{M}^{\text {pro }}\right)$

\begin{tabular}{llc}
\hline Ligands & $\begin{array}{l}\text { Binding affinity } \\
(\mathrm{kcal} / \mathrm{mol})\end{array}$ & $\begin{array}{l}\text { Inhibition } \\
\text { constant }(\mathrm{Ki}), \\
\mu \mathrm{mol}\end{array}$ \\
\hline $\mathbf{1}$ & -6.50 & 16.524 \\
$\mathbf{2}$ & -6.70 & 11.775 \\
$\mathbf{3}$ & -6.10 & 32.538 \\
$\mathbf{4}$ & -6.90 & 8.391 \\
$\mathbf{5}$ & -6.20 & 27.468 \\
$\mathbf{6}$ & -6.00 & 38.544 \\
Remdesivir & -7.00 & 7.084 \\
Chloroquine & -5.20 & 149.453 \\
Hydroxychloroquine & -5.60 & 75.898 \\
\hline
\end{tabular}

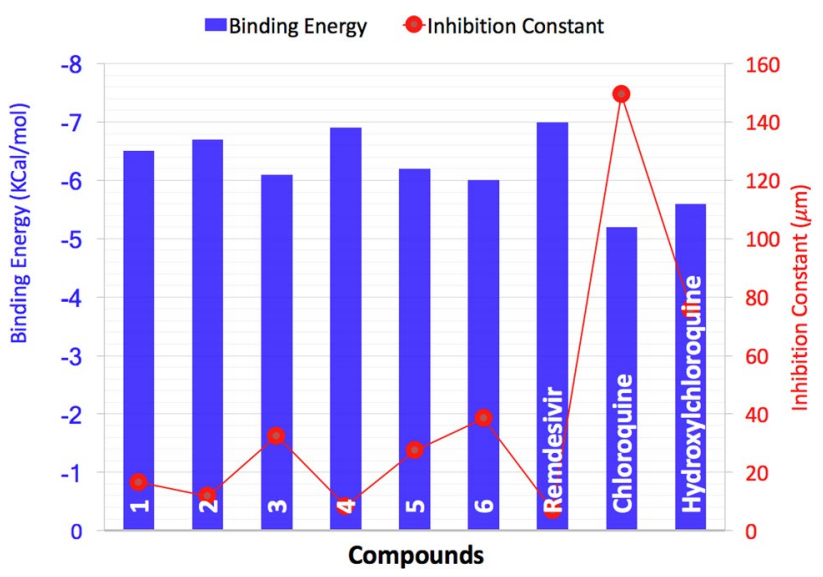

Fig. 1 Graphical representation of biding energy and inhibition constants for docked compounds 1-6 and commonly use therapeutic drugs for COVID-19

interaction energies, which are sum of all types of interaction energies. The interaction of ferrocenylethyl-thiosemicarbazone derivatives were studied against the main protease $\left(\mathrm{M}^{\mathrm{pro}}\right)$ of SARS-CoV-2 by using a grid-based technique and effectively dock the flexible ligand with rigid protein receptor. From the binding stability/tendency point of view, a more negative value indicates higher binding affinity with protein receptor. All the above reported values of binding energies were selected from the nine poses of each ligand with protein molecule where the selected respective pose showed zero RMSD value. The docking scores of the ferrocenylethyl-thiosemicarbazone derivatives after performing molecular docking are given in Table 1 and Fig. 1 in terms of their biding energies and inhibition constants. The binding energies are ranged from $-6.0 \mathrm{kcal} / \mathrm{mol}$ to $-6.9 \mathrm{kcal} / \mathrm{mol}$ for compound 6 to compound 4, respectively. Higher binding affinity showed the best fitting of ligand to protein cavity's active site. The binding affinities of the six compounds are 
found in the following decreasing order: compound $\mathbf{4}>\mathrm{com}$ pound $\mathbf{2}>$ compound $\mathbf{1}>$ compound $\mathbf{5}>$ compound $\mathbf{3}>$ compound $\mathbf{6}$. The two best docked ligands 2 and $\mathbf{4}$ possess the binding energies (inhibition constants) which are $-6.7 \mathrm{kcal} /$ $\mathrm{mol}(11.775 \mu \mathrm{mol})$ and $-6.9 \mathrm{kcal} / \mathrm{mol}(8.3919 \mu \mathrm{mol})$, respectively. The calculated binding energies of present investigation were also compared with some standard compounds. Till now, there is no therapeutic drug for COVID19 but some drugs have shown to be quite effective against COVID-19. For example, based on multiple clinical trials, the FDA has approved remdesivir as an antiviral drug for COVID-19 patients [44]. Similarly, NIH has also recommended chloroquine and hydroxychloroquine (originally an antimalarial drug) for treatment of COVID-19 [45]. Based on these recommendations, it will be at least semi-quantitatively useful to compare our ligands with previous drugs in the field. For this reason, we have also docked remdesivir, chloroquine and hydroxychloroquine molecules with $\mathrm{M}^{\text {pro }}$ of COVID-19 under the same calculation parameters as our compounds. The docked pose of remdesivir are given in Figure S1 of supporting information, which shows similar docking positions as our synthesized compounds with $\mathrm{M}^{\text {pro }}$. The calculated binding energies of remdesivir, chloroquine and hydroxychloroquine molecules with $\mathrm{M}^{\text {pro }}$ of COVID-19 are found to be $-7.00,-5.20$ and $-5.60 \mathrm{kcal} / \mathrm{mol}$, respectively. The comparative analysis of binding energies of ferrocenylethyl-thiosemicarbazone derivatives with those of three standard compounds showed a reasonable potential of our synthesized ferrocenylethyl-thiosemicarbazone derivatives to show inhibition potential for $\mathrm{M}^{\mathrm{pro}}$ of COVID-19. The binding energy of compound $4(-6.9 \mathrm{kcal} / \mathrm{mol})$ is almost equal to the remdesivir and greater than the binding energies of chloroquine and hydroxychloroquine. Thus, the present investigation of binding energies can give a quantitative guess about the real-time potential of our synthesized compounds for possible therapeutic drug candidate for $\mathrm{M}^{\text {pro }}$ of COVID-19. Similarly, the discussion about inhibition constants is also important which usually shows an inverse relation with binding energy and might be useful in finding some QSAR relations in future studies. The inhibition constants of compound $4(-6.9 \mathrm{kcal} / \mathrm{mol})$ and remdesivir are near to each other indicating their good inhibition tendencies.

\section{Intermolecular interactions of ligands and receptor}

The calculated interaction or binding energy is crucial parameter to judge the binding potential of a ligand to a protein respecter molecules. However, binding energy is not the only criterion to see the potential of ligand as possible therapeutic drug. The visualization of ligand orientations on protein receptor, their intermolecular interactions also play very crucial roles. Perhaps, the intermolecular interactions including hydrogen bonds, electrostatic, hydrophobic and hydrophilic interactions mainly control the binding tendencies of ligands to a specific protein.

Among our synthesized ferrocenylethyl-thiosemicarbazone derivatives, as compounds $\mathbf{2}$ and $\mathbf{4}$ showed larger binding energies with the $\mathrm{M}^{\mathrm{pro}}$, so we have visualized their intermolecular interactions by discovery studio visualizer. The most important are the interactions between ligand and active site residues of $\mathrm{M}^{\text {pro }}$ includes conventional hydrogen bonding, and hydrophobic interactions, $\pi-\pi$ interactions and $\pi$-alkyl interactions. The ligand $\mathbf{2}$ exhibited hydrogen bonding and hydrophobic interactions with catalytic site of main protease $\mathrm{M}^{\text {pro }}$. The two hydrogen bonds with THR292 and THR 111 residues are $2.13 \AA$ and $2.02 \AA$, respectively, as shown in Fig. 2 b. The $\pi-\pi$ and $\pi$-alkyl interactions are seen with PHE294, while a $\pi$-alkyl interaction with ILE106 shows a distance of about $3.17 \AA$. The ligand $\mathbf{4}$ also shows three main types of interactions with $\mathrm{M}^{\text {pro }}$ active site residues, hydrogen bonds with LUE287, TYR239, $\pi-\pi$ interactions with MET276 and $\pi$-alkyl interactions with LEU287 residues as shown in Fig. 2a-d. Among the hydrogen bonds, the LEU287 and TYR239 show distances of $2.43 \AA$ and $1.83 \AA$, respectively. Furthermore, the orientation of compounds 2 and 4 can be visualized from Fig. 3a-d on the total density surface of $\mathrm{M}^{\text {pro }}$ protein indicating a good fit of our compounds with the active cavities of $\mathrm{M}^{\text {pro }}$ protein of COVID-19.

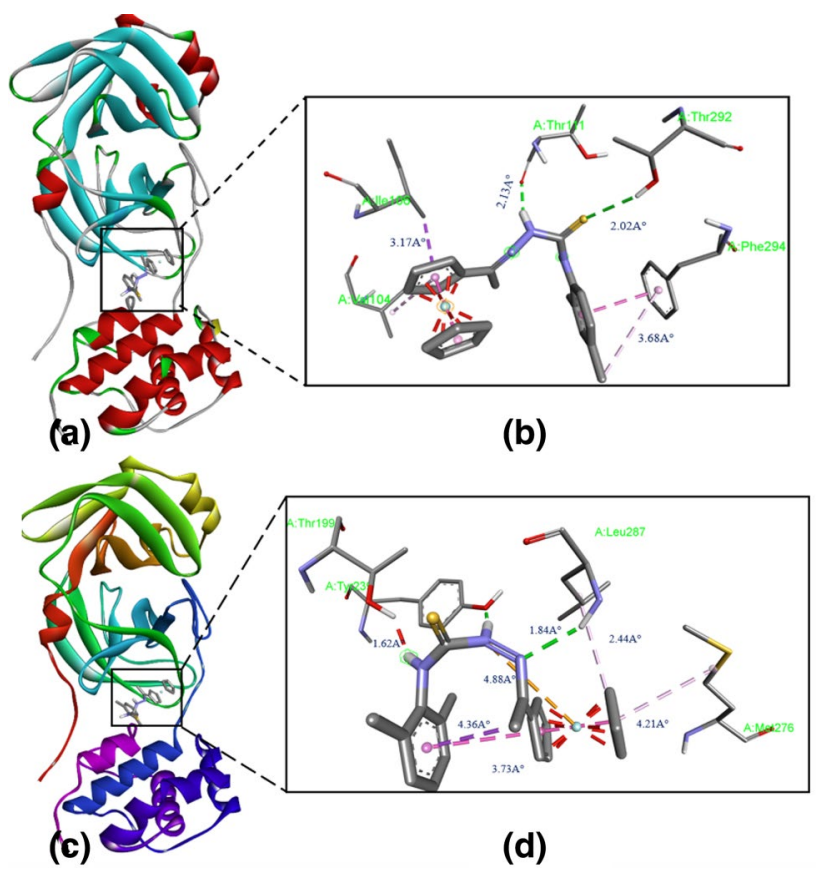

Fig. 2 Three-dimensional representation of compounds 2 (a and b) and $\mathbf{4}$ (c and d) showing their positions and interacting residues around the cavity of $\mathrm{M}^{\text {pro }}$ protein 
Fig. 3 Total density surfaces representations including compounds 2 (a and $\mathbf{b}$ ) and 4 (c and d) with $\mathrm{M}^{\text {pro }}$ protein where hydrogen bond donor and acceptor meshes represented by pink and green colors, while hydrophobic pockets are represented with blue and grey colors, respectively

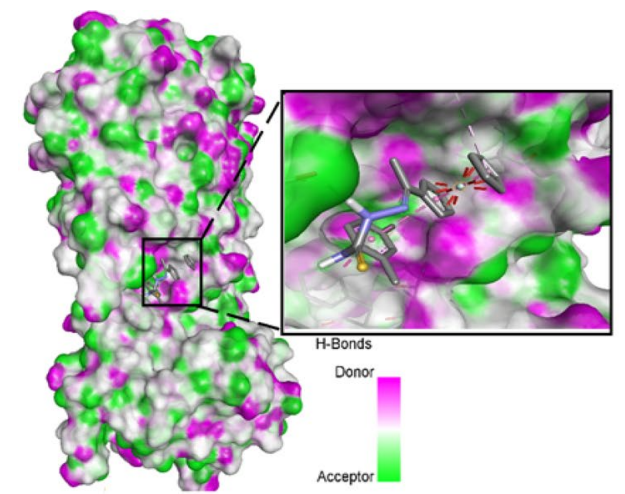

(a)

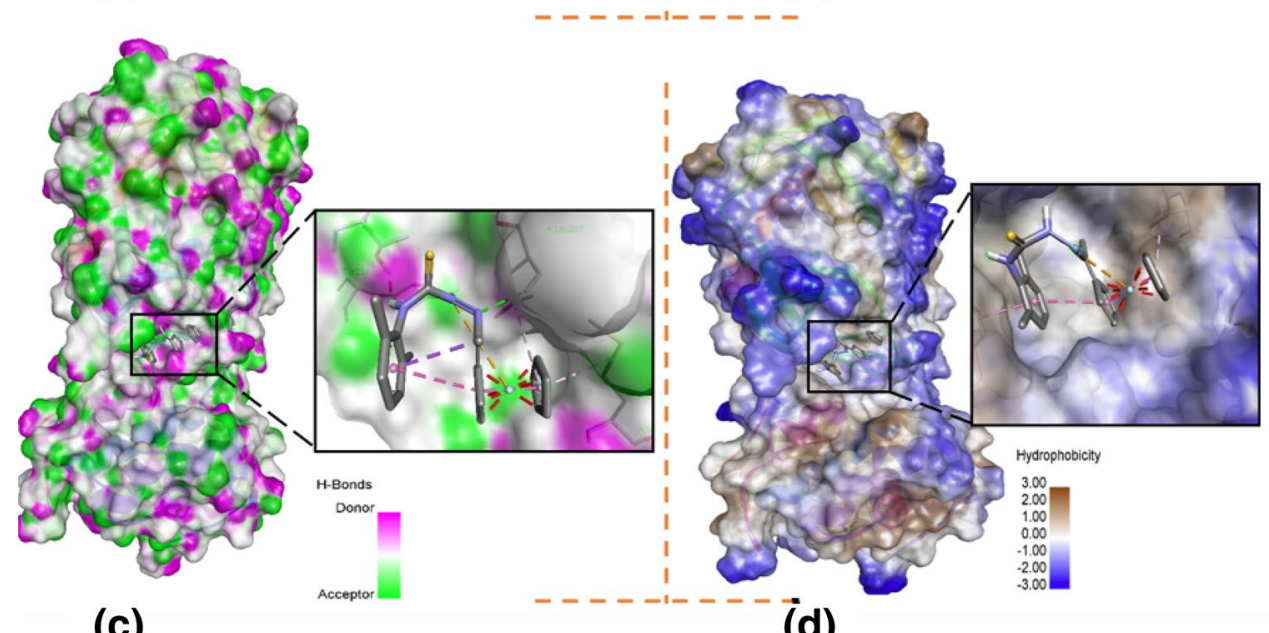

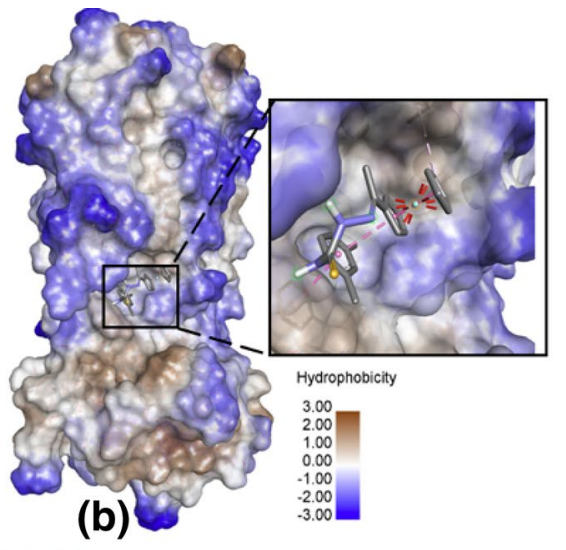

(d)

\section{Conclusion}

Six novel ferrocene-based thiosemicarbazone derivatives have been synthesized via condensation reaction and characterized through IR, ${ }^{13} \mathrm{CNMR}$ and ${ }^{1} \mathrm{HNMR}$ and mass spectrometry. Additionally, we have used computational docking approach to explore the theoretical aspects for possible antiviral activity of our synthesized compounds. All the six compounds were docked with $\mathrm{M}^{\text {pro }}$ protein of SARS-CoV-2. The binding affinities of the six compounds were found in the following decreasing order: compound $\mathbf{4}>$ compound $\mathbf{2}>$ compound $\mathbf{1}>$ compound $\mathbf{5}>$ compound $3>$ compound 6 . The two best docked compounds 2 and 4 possessed the binding energies (inhibition constants) which are $-6.7 \mathrm{kcal} / \mathrm{mol}(11.775 \mu \mathrm{mol})$ and $-6.9 \mathrm{kcal} /$ mol $(8.391 \mu \mathrm{mol})$, respectively. The intermolecular interactions between synthesized derivatives and $\mathrm{M}^{\text {pro }}$ protein illustrated that each of compounds $\mathbf{2}$ and $\mathbf{4}$ forms two strong hydrogen bonds accompanied by important hydrophobic interactions. The comparison of binding affinities with some recently approved drugs like remdesivir, chloroquine and hydroxychloroquine molecules showed that the binding energy of compound $4(-6.9 \mathrm{kcal} / \mathrm{mol})$ was almost equal to the remdesivir and greater than the binding energies of chloroquine and hydroxychloroquine. Thus, the current dual approach study showed that our synthesized ferrocene-based thiosemicarbazones might have potential for drug against SARS-CoV-2.

Supplementary Information The online version contains supplementary material available at https://doi.org/10.1007/s13738-021-02346-1.

Acknowledgements The authors from King Khalid University extend their appreciations to Deanship of Scientific Research at King Khalid University for funding the work through Research Project (GRP/211/42). For computer time, this research used the resources of the Supercomputing Laboratory at King Abdullah University of Science \& Technology (KAUST) in Thuwal, Saudi Arabia.

Authors' contributions RJ and MUK have performed experimental tasks after conceiving the idea for synthesis, MH and MS have helped in writing and data collection, while AH and SM worked on molecular docking study. Dr. AGA has run calculations and provided supervision to several computational tasks.

Funding All funding sources for current investigation are acknowledged in the manuscript.

Data availability The data that support the findings of this study are available on request from the corresponding author. The data are not publicly available due to privacy or ethical restrictions. 
Code availability There are no codes used in the present investigation.

\section{Declarations}

Conflict of interest It is stated that there is no conflict of interest among the authors.

\section{References}

1. T. Kealy, P. Pauson, Nature 168, 1039 (1951)

2. S.A. Miller, J.A. Tebboth, J.F. Tremaine, J. Chem. Soc. 632, 127-128 (1952)

3. M. Ibrahim, Anal. Chim. Acta 443, 63 (2001)

4. J. Dunitz, L. Orgel, Nature 171, 121 (1953)

5. E.W. Abel, N.J. Long, K.G. Orrell, A.G. Osborne, V. Šik, J. Organomet. Chem. 403, 195 (1991)

6. P. Stepnicka, Ferrocenes: Ligands, Materials and Biomolecules (Wiley, New York, 2008)

7. M. Tsukazaki, M. Tinkl, A. Roglans, B. Chapell, N. Taylor, V. Snieckus, J. Am. Chem. Soc. 118, 685 (1996)

8. Y. Nishibayashi, Y. Arikawa, K. Ohe, S. Uemura, J. Org. Chem. 61, 1172 (1996)

9. A. Singh, I. Lumb, V. Mehra, V. Kumar, Dalton Trans. 48, 2840 (2019)

10. X. Narváez-Pita, A.L. Rheingold, E. Meléndez, J. Organomet. Chem. 846, 113 (2017)

11. S. Realista, S. Quintal, P.N. Martinho, A.I. Melato, A. Gil, T. Esteves, M.D.D. Carvalho, L.P. Ferreira, P.D. Vaz, M.J. Calhorda, J. Coord. Chem. 70, 314 (2017)

12. Y.-Q. Hu, C. Gao, S. Zhang, L. Xu, Z. Xu, L.-S. Feng, X. Wu, F. Zhao, Eur. J. Med. Chem. 139, 22 (2017)

13. A. Hottin, F. Dubar, A. Steenackers, P. Delannoy, C. Biot, J.-B. Behr, Org. Biomol. Chem. 10, 5592 (2012)

14. A.J. Bard, L.R. Faulkner, Electrochem. Methods 2, 580 (2001)

15. M. Dabrowski, B. Misterkiewicz, A. Sporzyński, J. Chem. Eng. Data 46, 1627 (2001)

16. F.A. Larik, A. Saeed, T.A. Fattah, U. Muqadar, P.A. Channar, Appl. Organomet. Chem. 31, e3664 (2017)

17. D. Li, S. Song, C. Fan, Acc. Chem. Res. 43, 631 (2010)

18. Y. Wu, S. Liu, L. He, Anal. Chem. 81, 7015 (2009)

19. H. Cheng, Q.-M. Gu, Polymers 4, 1311 (2012)

20. K. Kinbara, T. Muraoka, T. Aida, Org. Biomol. Chem. 6, 1871 (2008)

21. K. Nikitin, H. Müller-Bunz, Y. Ortin, J. Muldoon, M.J. McGlinchey, J. Am. Chem. Soc. 132, 17617 (2010)

22. L. Peng, A. Feng, M. Huo, J. Yuan, Chem. Commun. 50, 13005 (2014)
23. S. Takahashi, J.-I. Anzai, Materials 6, 5742 (2013)

24. X. Sui, X. Feng, M.A. Hempenius, G.J. Vancso, J. Mater. Chem. B 1, 1658 (2013)

25. X.Y. Ling, D.N. Reinhoudt, J. Huskens, Pure Appl. Chem. 81, $2225(2009)$

26. S.Ø. Scottwell, J.D. Crowley, Chem. Commun. 52, 2451 (2016)

27. G. Jaouen, Bioorganometallics: Biomolecules, Labeling, Medicine (Wiley, New York, 2006)

28. A. Goel, D. Savage, S.R. Alley, P.N. Kelly, D. O'Sullivan, H. Mueller-Bunz, P.T. Kenny, J. Organomet. Chem. 692, 1292 (2007)

29. G. Gong, Y. Cao, H. Qian, Y. Zhou, H. Zhao, L. Li, F. Wang, G. Zhao, Chem. Commun. 54, 8312 (2018)

30. S. Martić, M. Labib, P.O. Shipman, H.-B. Kraatz, Dalton Trans. 40, 7264 (2011)

31. S.R. Bayly, P.D. Beer, G.Z. Chen, Ferrocene Sensors (Wiley Online Library, New York, 2008), p. 281

32. G.D. Brindley, O.D. Fox, P.D. Beer, J. Chem. Soc. Dalton Trans. 23, $4354(2000)$

33. P.D. Beer, J. Cadman, Coord. Chem. Rev. 205, 131 (2000)

34. S.R. Bayly, T.M. Gray, M.J. Chmielewski, J.J. Davis, P.D. Beer, Chem. Commun. 22, 2234 (2007)

35. C. Biot, W. Daher, N. Chavain, T. Fandeur, J. Khalife, D. Dive, E. De Clercq, J. Med. Chem. 49, 2845 (2006)

36. M. Hussain, R. Jawaria, Z. Shafiq, G. Abbas, M.M. Naseer, J. Organomet. Chem. 846, 121 (2017)

37. G. Morris, R. Huey, W. Lindstrom, J. Comput. Chem 30, 2785 (2009)

38. O. Trott, A.J. Olson, J. Comput. Chem. 31, 455 (2010)

39. D.S. Biovia, Discovery Studio Modeling Environment. [Google Scholar] (2017)

40. R. Dennington, T.A. Keith, J.M. Millam, Semichem Inc. Shawnee Mission KS (2016)

41. Z. Jin, X. Du, Y. Xu, Y. Deng, M. Liu, Y. Zhao, B. Zhang, X. Li, L. Zhang, C. Peng, Nature 582, 289-293 (2020)

42. R. Ramajayam, K.-P. Tan, P.-H. Liang, Recent Development of $3 C$ and $3 C L$ Protease Inhibitors for Anti-Coronavirus and AntiPicornavirus Drug Discovery (Portland Press Ltd., London, 2011)

43. Z. Ren, L. Yan, N. Zhang, Y. Guo, C. Yang, Z. Lou, Z. Rao, Protein Cell 4, 248 (2013)

44. FDA, FDA Approves First Treatment for COVID-19. https://www. fda.gov/news-events/press-announcements/fda-approves-first-treat ment-covid-19 (2020)

45. NIH, Chloroquine or Hydroxychloroquine With or Without Azithromycin. https://www.covid19treatmentguidelines.nih. gov/antiviral-therapy/chloroquine-or-hydroxychloroquine-withor-without-azithromycin/, 9th October, 2020. 